\title{
Diatom assemblages associated with turtle carapaces in the Neotropical region
}

\author{
Jhon Ch. Donato-Rondón ${ }^{1}$, Juan David González-Trujillo ${ }^{*}$, Buendy Romero ${ }^{2}$ \\ \& Maria I. Castro-Rebolledo ${ }^{3}$ \\ 1. Laboratorio de Diatomeas. Universidad Nacional de Colombia - Sede Bogotá. Bogotá, Colombia; \\ jcdonator@unal.edu.co,jdgonzalezt@unal.edu.co \\ 2. Universidad Nacional de Colombia - Sede Bogotá. Bogotá, Colombia; bcromerog@unal.edu.co \\ 3. Universidad de la Salle. Bogotá, Colombia; micastro@unisalle.edu.co \\ * Correspondence
}

Received 15-V-2018. C Corrected 18-VII-2018. Accepted 16-VIII-2018.

\begin{abstract}
Few studies have explored the ecology and interrelationship with other organisms of the many endangered freshwater turtle species inhabiting the Neotropical region. The focus of the current study was to shed light on the relationship between Neotropical turtle carapaces and primary producers, insofar as the surface of former constitutes a suitable substrate for the colonization and establishment of the latter. The under-explored relationship between turtle carapaces and the diatom assemblages inhabiting them was investigated and characterized in terms of taxonomic and biological traits (bio-volume, life-form, and attachment). The carapaces of seven native turtle species were surveyed. Among these carapaces, a total of 45 diatom taxa were found, and diatom taxa varied among turtle species. Podocnemis vogli and Podocnemis expansa supported more diverse diatom assemblages than Podocnemis lewyana, Rhinoclemmys diademata, and Rhinoclemmys melanosterna, which were dominated by Navicula spp. Analysis, further showed that carapace size did not explain differences in diatom diversity. However, a trait-based analysis suggests that both carapace roughness and an assemblage's successional stage might explain the differences in assemblage composition. Because turtles can serve as dispersal vectors, characterizing their epibiont diatom assemblages may contribute to our understanding of diatom distribution on larger scales, as well as, give us some clues as to the auto-ecology of turtles that help us to effectively determine conservation areas for these endangered species.
\end{abstract}

Key words: epizoic diatom; Neotropical turtle; carapace; diatom assemblages; trait; Colombia.

Donato-Rondón, J. Ch., González-Trujillo, J. D., Romero, B. \& Castro-Rebolledo, M. I.. (2018). Diatom assemblages associated with turtle carapaces in the Neotropical region. Revista de Biología Tropical, 66(4), 1362-1372.

The poor dispersal capabilities of diatoms represent a strong constraint to their spatial distribution along the longitudinal dimension of rivers (Kristiansen, 1996). Given the unidirectional nature of rivers, sessile microorganisms - such as diatoms - tend to be continuously dislodged from upstream to downstream sections of the river (Liu, Soininen, Han, \& Declerck, 2013). In order to offset individual losses and maintain viable populations in upstream sections, diatoms have a wide variety of strategies, such as increasing the number of generations per year, developing attachment mechanisms, and growing on animals which can carry them to upstream sections (Peterson \& Stevenson, 1989; Kristiansen, 1996; Tiffany, 2011). One such animal dispersal vector could be the turtle, for turtle carapaces provide a suitable substrate for diatoms, while turtles themselves travel long distances in the upstream 
direction (Fachín-Terán, Vogt, \& Thorbjarnarson, 2006; Souza, Raizer, Da Costa, \& Martins, 2008; Frick \& Pfaller, 2013; Ersanli \& Gönulol, 2015).

While the study of epizoic diatoms growing on the carapaces of marine turtles has been advanced considerably in recent years (Frick \& Pfaller, 2013; Majewska, Santoro, Bolaños, Chaves, \& De Stefano, 2015), such studies for freshwater turtles have remained scarce, and even more so in the Neotropical region, where epizoic diatoms in aquatic ecosystems have only been studied by Wetzel, van de Vijuer, Cox, and Ector (2010); Wetzel, van de Vijuer, Cox, Bicudo, and Ector (2012). The Wetzel studies described two new species of epizoic diatoms in the Amazon Basin - Luticola deniseae (Wetzel et al., 2010) and Tursiocola podocnemicola (Wetzel et al., 2012) - and hypothesized that the presence of both these species in freshwater ecosystems is closely linked to the presence of both turtles and river dolphins, as these animals play a key role both as substrates and as dispersal vectors. However, how assemblage composition may vary among turtle species, has hardly been explored.

Habitat fragmentation, illegal trafficking, and hunting currently pose a great threat to the continued existence and livelihood of Neotropical freshwater-turtles (Rhodin et al., 2011; Páez, Morales-B, Lasso, Castaño, \& Bock, 2012). Gaining knowledge of these turtles' ecology is, moreover, crucial for designing effective measures to ensure their conservation. A first step in this direction is characterizing the epizoic assemblages inhabiting their carapaces, since species composition might be related not to only environmental conditions but also the autoecology of the turtles (Soylu, Gönulol, Sukatar, Ayaza, \& Tok, 2006). Majewska et al. (2015), for instance, found that some diatom traits served as bio-indicators for marine turtle foraging sites. Furthermore, Soylu et al. (2006) suggested that the abundance of some epibiont species is explained by the feeding behaviour of some freshwater turtle species. These autoecological aspects of turtles may contribute to the estimation of their home range, which is a relevant factor in delineating conservation areas (Stamps \& Swaisgood, 2007).

The aim of this study was to assess and compare diatom assemblages inhabiting carapaces of some of the endangered turtle species in the Neotropical region. Diatom assemblages were sampled from turtles kept in captivity and cared for by the specialists at the Roberto Franco Tropical Station (Villavicencio, Colombia). Although kept in one place, characterizing diatom assemblages from carapaces different in form and size represents a great opportunity (1) to study the degree of association between diatom assemblages and turtle species and (2) to evaluate if various turtle species could disperse diatoms equally as well. If there are specific associations between turtle and diatom species, characterizing diatom assemblages would be useful for improving turtle conservation plans. Specific associations could serve as proxies of turtle's feeding behaviour and foraging sites, or population's connectedness, which are important elements for delineating species home range.

\section{MATERIALS AND METHODS}

Study site: The study was carried out at the Roberto Franco Station for Tropical Biology (Villavicencio, Colombia). As a part of a conservation and rehabilitation program, the station cares for reptile species recovered from illegal traffickers. Freshwater turtles are maintained in artificial ponds with a surface area of $9 \mathrm{~m}^{2}$ and a maximum depth of approximately $0.6 \mathrm{~m}$. The pond water is renewed with river or ground water every $15 \mathrm{~d}$. Water quality parameters varied only slightly among ponds. The average water temperature was $25.9{ }^{\circ} \mathrm{C}$ (Standard Error from the Mean - 'SE' $=0.45$, $\mathrm{n}=7) ; \mathrm{pH} 6.19$ (SE = 0.09); and dissolved oxygen concentration $4.9 \mathrm{mg} / \mathrm{L}(\mathrm{SE}=0.21)$. The average conductivity was $106.3 \mu \mathrm{s} / \mathrm{cm}$ (SE $=0.75)$; nitrate concentration $0.24 \mathrm{mg} / \mathrm{L}(\mathrm{SE}=$ 0.08); phosphate concentration $1.2 \mathrm{mg} / \mathrm{L}$ ( $\mathrm{SE}=$ 0.25 ); and ammonium concentration $1.5 \mathrm{mg} / \mathrm{L}$ $(\mathrm{SE}=0.3)$. 
Each pond contained between three and 15 individuals of the same species, which were fed according to their natural diets. Turtle carapaces of seven native species were sampled on December 1 1st 2015: Rhinoclemmys melanosterna (Gray, 1981) or "Palmera" ( $\mathrm{n}=$ 3); Rhinoclemmys diademata (Mertens, 1954) or "Inguensa" ( $\mathrm{n}=3)$; Kinosternon dunni (Schmidt, 1947) or "Morrocoy de Dunn" (n = 3); Podocnemis lewyana (Duméril, 1852), o "Tortuga de río" $(\mathrm{n}=3)$; Podocnemis unifilis (Troschel, 1848) or "Terecay" ( $\mathrm{n}=3)$; Podocnemis vogli (Müller, 1835) or "Galápago" $(\mathrm{n}=3)$; and, Podocnemis expansa (Schweigger, 1812) or "Charapa" $(\mathrm{n}=3)$. At the time of sampling, the carapaces of all turtle species had not been cleaned by station staff for about a month, thus allowing sufficient time for diatom colonization (Stevenson, Bothwell, Lowe, \& Thorp, 1996). See Páez et al. (2012) for details about species biology and conservation status.

Diatom sampling and processing: For each species, three individuals were randomly selected for study. The total area of each carapace was measured by tracing the carapace onto paper with a known weight per area, and then weighing the paper. For each carapace, an area of approximately $19.2 \mathrm{~cm}^{2}$ (divided into three sections by a slide frame) was brushed with a tooth brush. The samples thus obtained were preserved in $4 \%$ formalin. In the laboratory, samples were oxidized using $30 \%$ hydrogen peroxide and mounted on slides using Naphrax ${ }^{\circledR}$ following the protocol described in Bellinger and Sigee (2015). A total of 400 valves were counted for each sample, except those from $P$. unifilis and $P$. vogli, for which only 100 valves were counted owing to their low abundance on slides. Diatoms were identified to the lowest taxonomic-level possible following specialized keys (Krammer \& Lange-Bertalot, 1986, 1991; Metzeltin \& Lange-Bertalot, 1998, 2007; Rumrich, LangeBertalot, \& Rumrich, 2000).

Data analysis: The structure and composition of diatom assemblages were characterized using taxonomical and trait-based approaches. Taxa richness and Simpson indices were used to compare diatom diversity among turtle species. Comparisons were made using pairwise T-tests adjusted by the Bonferroni correction. A generalized model was used to test the relationship between carapace area and diatom richness, while a linear model was used to investigate the connection between carapace area and diatom diversity. An ANOSIM analysis (Clarke, 1993) was used to compare assemblage composition among turtle species, and non-Metrical multidimensional scaling ('nMDS'; Kruskal, 1964) was used to explore how the taxonomical composition varied among turtle species. The Horn Index was selected as the distance index for this ordination, since it does not give so much weight to rare taxa (Jost, Chao, \& Chazdon, 2011). A posterior ANOSIM analysis was performed to evaluate if the groups of turtles drawn by the nMDS were different in terms of diatom species composition.

Three traits - diatom biovolume, life-form, and the type of attachment - were used to assess the functional composition of the diatom assemblages. Each species or genus was assigned to one trait category following Lange et al. (2016). According to these authors, valve biovolume has five categories: nano $(5 \leq 100$ $\left.\mu \mathrm{m}^{3}\right)$, micro $\left(100 \leq 300 \mu \mathrm{m}^{3}\right)$, meso $(300 \leq$ $\left.600 \mu \mathrm{m}^{3}\right)$, macro $\left(600 \leq 1500 \mu \mathrm{m}^{3}\right)$, and large $\left(>1500 \mu \mathrm{m}^{3}\right)$. Life-form has two categories: 'colonial' or 'solitary'. And, type of attachment has three categories: 'tightly-attached', 'attached', and 'not-attached'. Trait data were obtained from existing trait-databases (Lange et al., 2016) and complemented by observations in the laboratory, e.g. diatom biovolume being identified to the genus-level. For each turtle species, the relative abundance of diatoms possessing a specific trait category was presented in the form of stacked bar graphs. Trait and ordination analyses were performed using the relative abundances of the traits. All analyses and figures were done in R language (R Core Team, 2016) using the package 'Vegan' (Oksanen et al., 2013). 


\section{RESULTS}

A total of 45 diatom species were found among all carapaces sampled from the turtle seven species (Appendix), and diatom species composition differed among the turtle species (ANOSIM R $=0.665, \mathrm{P}<0.001$, permutations $=9999)$. In fact, three distinct groups of turtle species (Fig. 1) can be defined, each with a significantly different diatom species composition (ANOSIM R $=0.965, \mathrm{P}<0.001$, permutations $=9$ 999). The first group (Group 1) consisted of turtle species whose carapaces' diatom assemblages were dominated by Navicula sp., namely $R$. melanosterna, $R$. diademata, and $P$. lewyana. The second group (Group 2) included the other four turtle species (K. dunni, $P$. unifilis, $P$. vogli, and $P$. expansa) and was characterized by highly diverse diatom compositions. The third group (Group 3) consisted of just one turtle, which as one of the three individuals from the species $P$. vogli and differed from the members of Group 2 in terms of its composition. Certain diatom species were only found on the carapace of this one individual. These species included Brachysira serians, Aulacoseira sp., Eunotia exigua, Gomphonema insigne, and Stauroneis anceps.

Regression models showed that carapace area was neither a good descriptor of species richness nor of species diversity among the epibiont diatom assemblages (Fig. 2), for the greatest richness and diversity were observed in four species with significantly different carapace areas: $P$. expansa, $P$. unifilis, $K$. dunni and $P$. vogli; Kruskal-Wallis test: $\mathrm{H}$-value $=9, \mathrm{df}=$ $3, \mathrm{P}=0.03$. (Fig. 3A). T-test pairwise comparisons showed that richness and diversity were not statistically different among these four species $(\mathrm{P}>0.05)$, but that there was a statistically significant difference between those four species and $R$. melanosterna, $R$. diademata, and $P$. lewyana $(\mathrm{P}<0.01)$. Consequently, in terms of richness and diversity, it can be said that there were two groups of turtles: one with diverse diatoms assemblages and another with assemblages composed of five or less diatoms species (Fig. 3).

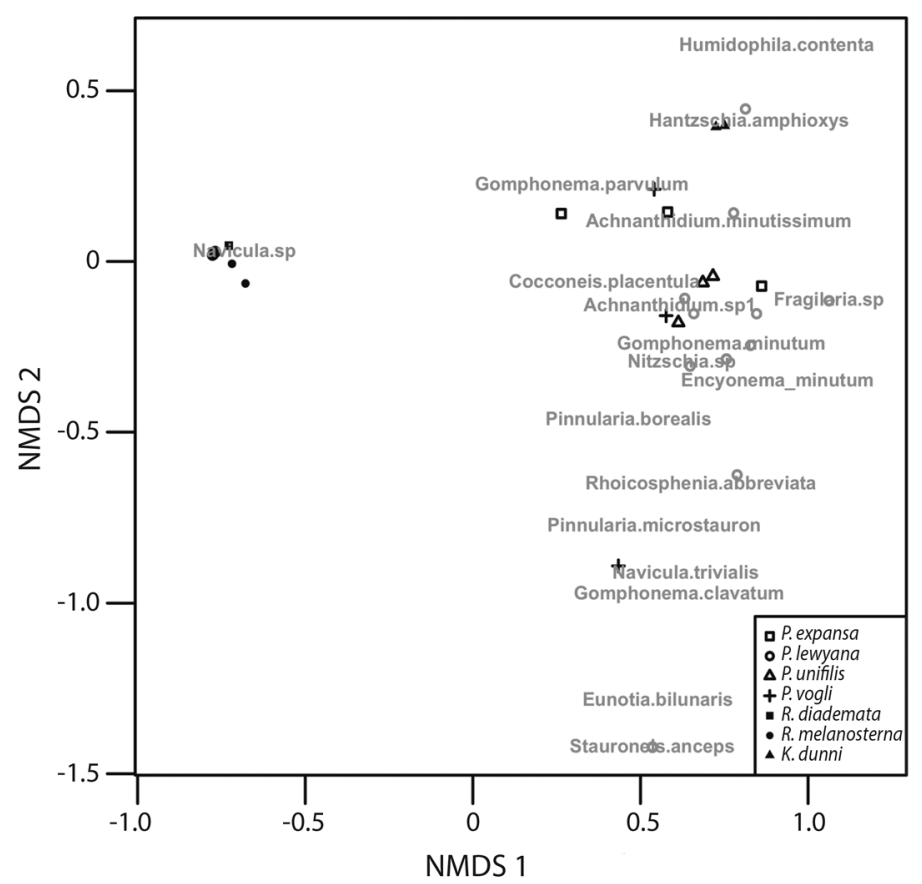

Fig. 1. Non-metrical multidimensional scaling (nMDS) plot using the Horn-distance index. Turtle species are ordered according to the composition of diatom assemblages inhabiting their carapaces (Stress $=0.019$ ). 

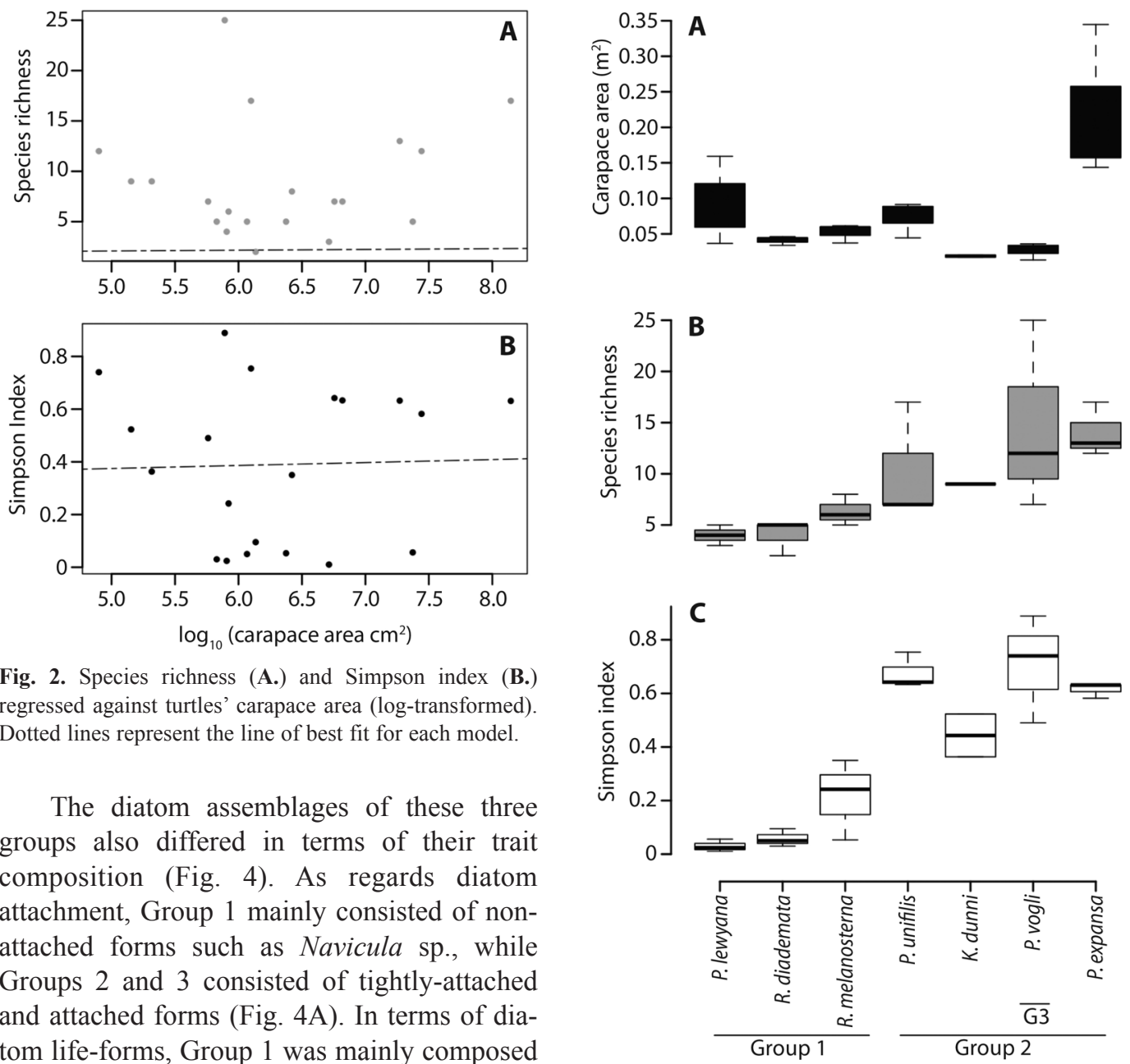

Fig. 2. Species richness (A.) and Simpson index (B.) regressed against turtles' carapace area (log-transformed). Dotted lines represent the line of best fit for each model.

The diatom assemblages of these three groups also differed in terms of their trait composition (Fig. 4). As regards diatom attachment, Group 1 mainly consisted of nonattached forms such as Navicula sp., while Groups 2 and 3 consisted of tightly-attached and attached forms (Fig. 4A). In terms of diatom life-forms, Group 1 was mainly composed of solitary life-forms, whereas Groups 2 and 3 were principally populated by colonial lifeforms (Fig. 4B). As for biovolumme, all Group 1 diatoms were in the "micro" category, with the exception of two Achnanthidium species which were in the "nano" category. In contrast, Groups 2 and 3 mainly consisted of "nano" diatoms, although some diatoms belonging to other size categories were also present (Fig. $4 \mathrm{C})$. The relative abundance of biovolume categories varied among the turtle species, with the greatest diversity in biovolume occurring in $P$. vogli. For this reason, the difference between $P$. vogli individual from Groups 2 and 3 was further investigated (Fig. 5). The Group 3 individual was found to differ from those in Group 2 on account of a greater abundance of

Fig. 3. Box-and-whiskers plot of carapace size (A.), species richness (B.), and diversity in terms of Simpson index (C.) of diatom assemblages inhabiting the different turtle species. Turtles have been ordered along the $\mathrm{x}$-axis from lowest to highest species richness.

larger diatoms (categories defined by sizes $>$ $300 \mu \mathrm{m}^{3}$ ), which were tightly-attached and/or had colonial life-forms.

\section{DISCUSSION}

This study is one of the first to assess and compare the association between turtle carapaces and the diatom life-forms inhabiting them, in the Neotropical region. Although 

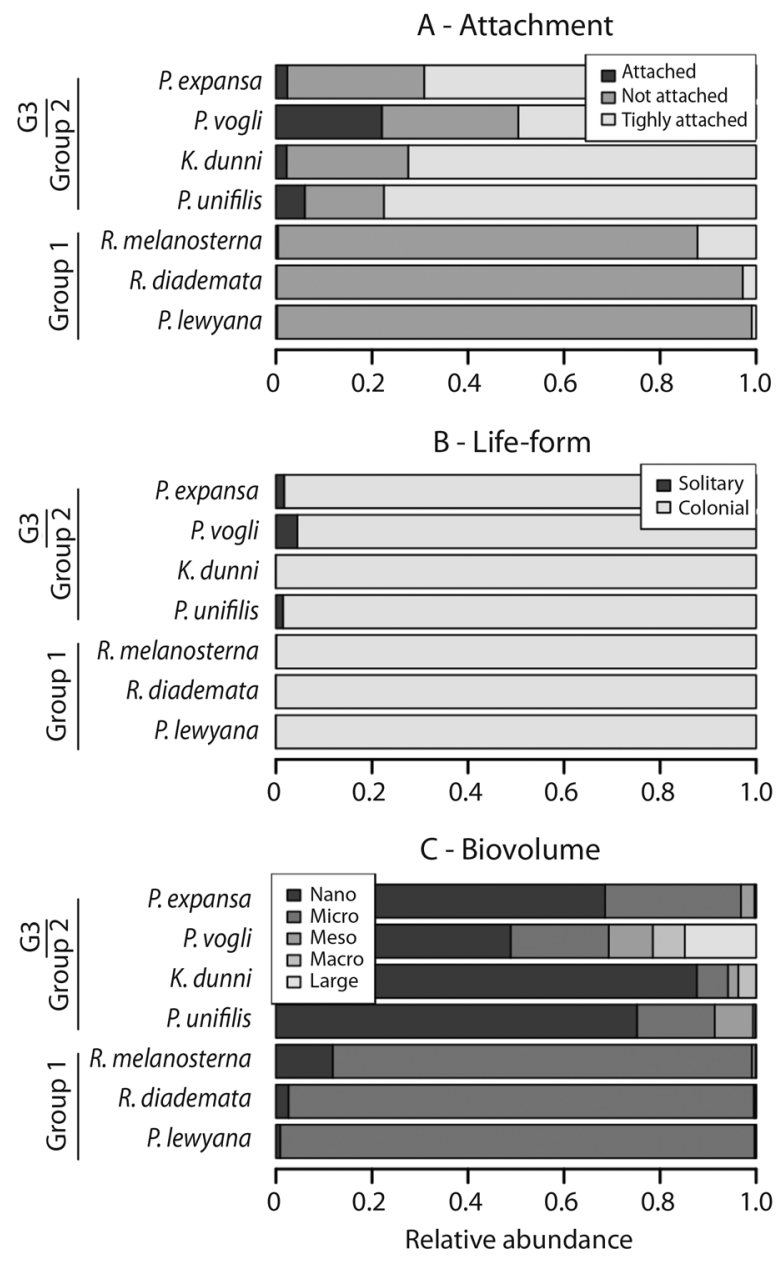

Fig. 4. Trait composition of diatom assemblages inhabiting turtle carapaces. Turtle species are ordered, from bottom to top, according to increasing diatom species richness.

it is a small-scale study carried out on turtles in captivity, its findings show that turtle carapaces are not uniformly colonized by the same diatom species. Two general groups of turtles, defined by the structure and composition of their diatom assemblages, emerged: One whose carapaces were colonized by only one or two diatom species (e.g. Navicula sp. or Achnanthidium sp.) and another whose carapaces were colonized by a diversity of diatom species with diverse traits. Given that the artificial ponds were similar to each other in terms of water quality and physical disturbance, diatom assemblage structure and composition on turtle carapaces might be dependent on several extrinsic and intrinsic factors, such as carapace size, physical stress or competence, and the regional pool and successional stage of assemblages (Tumlison \& Clark, 1996; Soylu et al., 2006; Wu \& Bergey, 2017). This study's results suggest that carapace size is not the best descriptor of diatom richness and diversity. Although carapace roughness and successional stage were not directly measured, the analysis of assemblage trait compositions suggests that these two factors could explain the observed differences between carapaces in terms of species richness, composition, and diversity. 

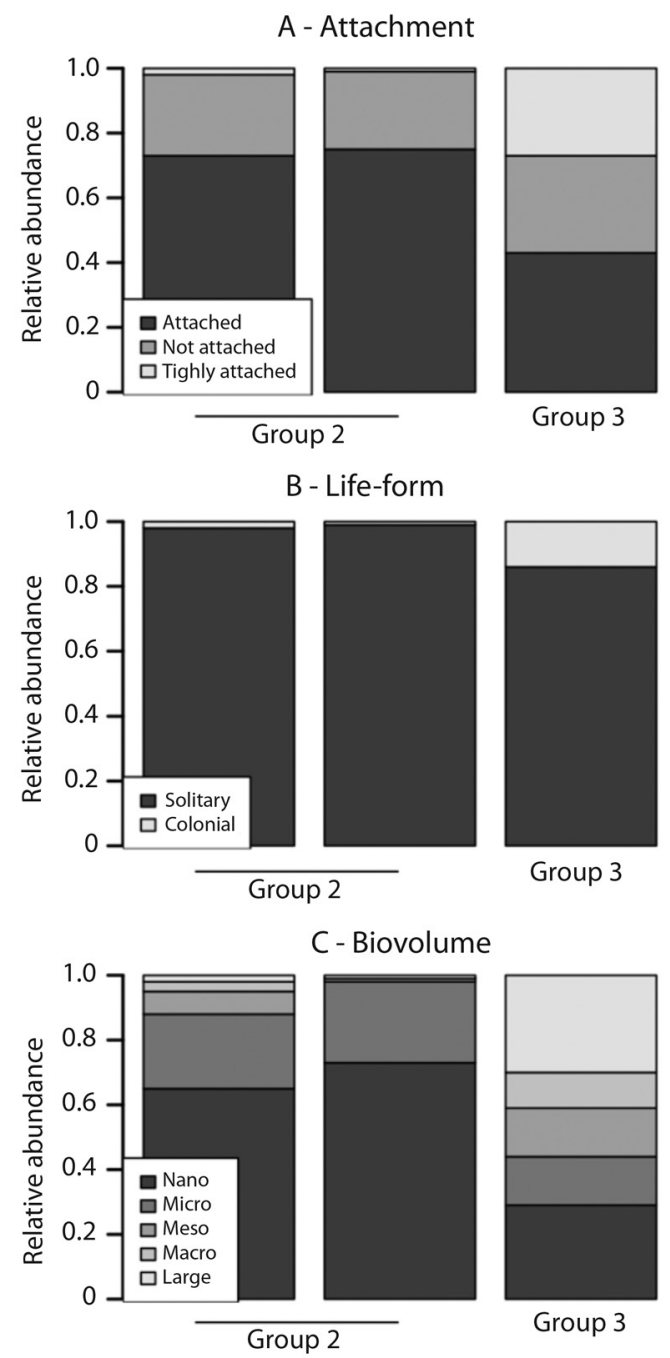

Fig. 5. Trait composition of diatom assemblages inhabiting Podocnemis vogli carapaces. The left two columns represent the compositions of two individuals from Group 2, while the right-most column represents the composition of the Group 1 individual.

As regards carapace roughness, the attachment point theory (Scardino, Harvey, \& De Nys, 2006; Scardino, Guenther, \& De Nys, 2008) states that substrate roughness constrains the presence of diatoms, depending on their valve size or attachment form. Hence, since only small diatoms with smaller points of attachment ("non-attached" category), such as Navicula sp., are capable of inhabiting rough substrates (Sweat \& Johnson, 2013), it can be reasoned that the turtle carapaces with less diatom diversity (e.g. carapaces of $R$. melanoster$n a, R$. diademata and P. lewyana) were rougher. In contrast, bigger diatoms with larger points of attachment are capable of colonizing smooth substrates (Sweat \& Johnson, 2013). From this, it follows that the turtles species inhabited by larger and attached or highly-attached diatoms (such as Cocconeis placentula, Gomphonema parvulum, Placoneis elginensis) had smooth carapaces. Because these latter diatom species were common on the carapaces of $K$. dunni, $P$. vogli, P. unifilis, and P. expansa, it is likely that these turtle species had smooth carapaces. The foregoing implies that carapace roughness might be an important factor in determining the structure of epizoic assemblages. Nonetheless, actual measurements of carapace roughness are needed in order to confirm this hypothesis.

The successional trajectories of each diatom assemblage could also explain the three groups of turtles defined in the nMDS. The $P$. vogli individual, which constituted Group 3, had a greater richness of unique species than the turtles in Group 2. These unique species were mainly unattached diatoms of larger size (meso, macro, and larger categories). Diatoms with these traits (e.g. Eunotia binularis, Gomphonema insigne, Gomphonema clavatum, Pinnularia microstauron) are characteristic of late-successional stages (Stenvenson et al., 1996 and references therein), suggesting that the assemblage of the $P$. vogli individual had reached a more advanced successional stage at the time of the sampling. Considering that all the carapaces had not been cleaned for about a month, the early-successional assemblages observed in Group 1 appear to be more linked to carapace roughness, as discussed above, or other factors inhibiting assemblage development, as will be described below.

This study's results may also have been influenced by a number of unmeasured factors, such as: (1) the overall "regional" pool of diatom species in the ponds, (2) the time that the turtles spent outside the water, and (3) biofilm thickness. The regional diatom species pool can be a major explanatory factor of diatom 
richness on turtle carapaces. Wu and Bergey (2017), for instance, showed that biogeographical patterns in diatom species explained the species composition on the carapaces of turtles from different regions of the United States. Consequently, characterizing the available diatom species pool in turtle habitats could improve our understanding of the relationship between the "regional" and local species pools inhabiting carapaces. On the other hand, Tumlison and Clark (1996) stated that the movement behaviour of turtles affects carapace appearance (clean, muddy or mossy), which, in turn, constrains the richness of epibiont species. $R$. melanosterna and $R$. diademata are turtles that spend a significant amount of time outside the water, that is to say, they are "semiaquatic turtles" (Páez et al., 2012). Their time outside the water could be a stress factor affecting biofilm thickness and, consequently, the composition of epibiont diatoms on their carapaces. Species capable of colonizing carapace crevices might be more tolerant to this stressor (Bergey 1999, 2005) and, hence more likely to populate the carapaces of semiaquatic turtles. In light of the foregoing, measuring the overall "regional" pool of diatom species, the time that the turtles spend outside the water, and biofilm thickness appear be essential for determining what actually gives rise to the structure of epibiont communities in aquatic ecosystems.

Several studies have demonstrated that characterizing epibiont assemblages give some clues as to the auto-ecology of turtles, which is of great importance in effectively delineating conservation areas based on feeding behaviour (Soylu et al., 2006), foraging sites (Majewska et al., 2015), and/or the degree of connectivity between populations of the same species (Caine, 1986). Our results give a first indication 1) as to which diatom species might be prone to inhabit the carapaces of a certain turtle species and 2) as to why this might be the case. While carapace roughness emerged as the most plausible hypothesis for explaining this relation, other species-specific behavioral factors, such as feeding behavior and time spent outside the water, might be also relevant.
Further research, both in captivity and in natural conditions, is needed to establish which of these factors give rise to the structure of diatom assemblages. Once the relationship between these factors and diatom assemblage structure has been established, the latter could serve as a proxy for species auto-ecology and be used for designing conservation plans. An example of this is Caine (1986), who, by assessing epibiont communities, found that conservation plans for loggerhead sea turtles required a reappraisal because of the disconnection between populations along the Atlantic coast of the USA.

Characterizing epibiont assemblages on turtle carapaces can also contribute to our understanding of diatom distribution on larger scales. Unidirectional streams and rivers restrict diatom recolonization in upstream zones (Kristiansen, 1996). It has been suggested that non-attached diatoms are more abundant in low zones of a river network, as they are less resistant to flow-induced stress (Liu et al., 2013). Thus, these diatoms should have a mechanism to persist and recolonize upstream zones (Kristiansen, 1996). Our findings show that non-attached diatoms can colonize turtle carapaces, suggesting that turtles could be vectors moving non-attached diatoms to the rivers' upstream sections. Nevertheless, further research is needed to establish what the potential role of turtles is in the recolonization of diatom species in upstream zones.

\section{ACKNOWLEDGMENTS}

This study was financed by the Facultad de Ciencias at Universidad Nacional de Colombia (HERMES project code: 31732). The authors would like to thank the two anonymous reviewers for their helpful commentaries and to Neil Hunt for correcting, and greatly improving, the English text. Special thanks to the staff at the Roberto Franco Biology Station for their invaluable assistance, and especially to Maria Cristina Ardila and Pedro Sánchez who resolved key questions about the turtles' ponds, origin, and treatment in captivity. 


\section{RESUMEN}

Diatomeas epizoicas de los caparazones de tortugas de la región Neotropical. De las especies de tortugas en estado crítico o vulnerable de conservación que habitan en la región Neotropical, son pocos los estudios que han ahondado en su ecología o relaciones con otros tipos de organismos. El presente estudio buscó caracterizar la asociación existente entre las diatomeas y el caparazón de especies de tortugas neotropicales, ya que este representa un sustrato adecuado para la colonización y establecimiento de este grupo de algas. Esta asociación fue estudiada considerando tanto la composición de especies como la de rasgos biológicos (biovolumen, forma de vida, y forma de adherencia) de la comunidad de diatomeas. En los caparazones de las 7 especies de tortugas muestreadas se encontraron un total de 45 táxones. La composición de táxones varió entre los caparazones de las especies. Se encontró una mayor diversidad en los caparazones de Podocnemis vogli y Podocnemis expansa, mientras que en Podocnemis lewyana, Rhinoclemmys diademata, y Rhinoclemmys melanosterna se encontró una comunidad de baja diversidad dominada principalmente por Navicula sp. Los resultados sugirieron que la rugosidad del caparazón junto al estado de la sucesión pueden explicar las diferencias observadas en la composición de táxones de los diferentes caparazones. Debido a que las tortugas pueden funcionar como vectores de dispersión, caracterizar las comunidades que pueden crecer sobre sus caparazones podría contribuir a entender la distribución de las diatomeas a escalas mayores. Además, esta caracterización podría darnos pistas clave para la delimitación de áreas de conservación efectivas para las especies más amenazadas.

Palabras clave: epibiontes; diatomeas; tortugas neotropicales; caparazón; rasgos biológicos; Colombia.

\section{REFERENCES}

Bellinger, E. G., \& Sigee, D. C. (2015). Freshwater algae: identification and use as bioindicators. New Yersey, USA: Wiley-Blackwell.

Bergey, E. A. (1999). Crevices as refugia for stream diatoms: effect of crevice size on abraded substrates. Limnology and Oceanography, 44(6), 1522-1529.

Bergey, E. A. (2005). How protective are refuges? Quantifying algal protection in rock crevices. Freshwater Biology, 50(7), 1163-1177.

Caine, E. A. (1986). Carapace epibionts of nesting loggerhead sea turtles: Atlantic coast of USA. Journal of Experimental Marine Biology and Ecology, 95(1), 15-26.

Clarke, K. R. (1993). Non-parametric multivariate analyses of changes in community structure. Austral Ecology, 18(1), 117-143.
Ersanli, E. T., \& Gonulol, A. (2015). Epizoophyte composition on spotted turtle Emys orbicularis (Linnaeus, 1758 ) in Turkey. Bangladesh Journal of Botany, 43(2), 157-161.

Fachín-Terán, A., Vogt, R. C., \& Thorbjarnarson, J. B. (2006). Seasonal movements of Podocnemis sextuberculata (Testudines: Podocnemididae) in the Mamiraua sustainable development reserve, Amazonas, Brazil. Chelonian Conservation and Biology, 5(1), 18-24.

Frick, M. G., \& Pfaller, J. B. (2013). Sea turtle epibiosis. In J. Wyneken, K. J. Lohmann, \& J. A. Musick (Eds.), The Biology of Sea Turtles (Vol. 3, pp. 399-426). Boca Raton, USA: CRC Press.

Jost, L., Chao, A., \& Chazdon, R. L. (2011). Compositional similarity and $\beta$ (beta) diversity. In A. Magurran \& G. J. McGill (Eds.), Biological diversity: frontiers in measurement and assessment (pp. 66-87). New York, USA: Oxford University Press.

Kramer, K., \& Lange-Bertalot, H. (1986). Bacillariphyceae, 1. Teil: Naviculaceae. Jena, Germany: Gustav Fisher Verlag.

Kramer, K., \& Lange-Bertalot, H. (1991). Bacillariphyceae, 3. Teil: Centrales, Fragilariaceae, Eunotiaceae. Jena, Germany: Gustav Fisher Verlag.

Kristiansen, J. (1996). Dispersal of freshwater algae - a review. In J. Kristiansen (Ed.), Biogeography of Freshwater Algae (pp. 151-157). Netherlands: Springer Netherlands.

Kruskal, J. B. (1964). Multidimensional scaling by optimizing goodness of fit to a nonmetric hypothesis. Psychometrika, 29(1), 1-27.

Lange, K., Townsend, C. R., \& Matthaei, C. D. (2016). A trait-based framework for stream algal communities. Ecology and Evolution, 6(1), 23-36.

Liu, J., Soininen, J., Han, B. P., \& Declerck, S. A. (2013). Effects of connectivity, dispersal directionality and functional traits on the metacommunity structure of river benthic diatoms. Journal of Biogeography, 40(12), 2238-2248.

Majewska, R., Santoro, M., Bolaños, F., Chaves, G., \& De Stefano, M. (2015). Diatoms and other epibionts associated with olive ridley (Lepidochelys olivacea) sea turtles from the Pacific Coast of Costa Rica. PloS one, 10(6), e0130351.

Metzeltin, D., \& Lange-Bertalot, H. (1998). Tropische Diatomeen in Sudamerika I. 700 uberwiegend wening bekannte oder neue Taxa reprasentativ aals Elemente der neotropischen Flora. Iconographia Diatomologica, 5 .

Metzeltin, D. \& Lange-Bertalot, H. (2007). Tropical diatoms of South America II. Special remark on 
biogeographic disjunction. Iconographia Diatomologica, 18, 1-876.

Oksanen, J., Blanchet, F. G., Kindt, R., Legendre, P., O'hara, R. B., Simpson, G. L., ... \& Wagner, H. (2010). vegan: Community Ecology Package. $R$ package version 2.4-3. R Foundation for Statistical Computing. Vienna, Austria. Retrieved from https:// CRAN.R-project.org/package $=$ vegan

Páez, V. P., Morales Betancourt, M. A., Lasso, C. A., Castaño Mora, O. V., \& Bock, B. (2012). Biología y conservación de las tortugas continentales de Colombia (No. Doc. 26065) CO-BAC, Bogotá). Bogotá, Colombia: Instituto de Investigación de Recursos Biológicos Alexander von Humboldt.

Peterson, C. G., \& Stevenson, R. J. (1989). Substratum conditioning and diatom colonization in different current regimes. Journal of Phycology, 25(4), 790-793.

R Core Team. (2016). R: A language and environment for statistical computing. R Foundation for Statistical Computing. Vienna, Austria. Retrieved from https:// www.R-project.org/

Rhodin, A. G. J., Walde, A. D., Horne, B. D., Van Dijk, P. P., Blanck, T., \& Hudson, R. (2011). Turtles in trouble: the world's $25+$ most endangered tortoises and freshwater turtles-2011. Lunenburg, Canada: Turtle Conservation Coalition.

Rumrich, U., Lange-Bertalot, H., \& Rumrich, M. (2000). Diatoms of the Andes: From Venezuela to Patagonia/ Tierra del Fuego and two additional contributions. Iconographia Diatomologica, 9, 1-673.

Scardino, A. J., Guenther, J., \& De Nys, R. (2008). Attachment point theory revisited: the fouling response to a microtextured matrix. Biofouling, 24(1), 45-53.

Scardino, A. J., Harvey, E., \& De Nys, R. (2006). Testing attachment point theory: diatom attachment on microtextured polyimide biomimics. Biofouling, 22(1), 55-60.

Souza, F. L., Raizer, J., Da Costa, H. T. M., \& Martins, F. I. (2008). Dispersal of Phrynops geoffroanus (Chelidae) in an urban river in central Brazil. Chelonian Conservation and Biology, 7(2), 257-261.
Soylu, E. N., Gönülol, A., Sukatar, A., Ayaz, D., \& Tok, C. V. (2006). Epizoic Freshwater Algae on Emys orbicularis (Testudinata: Emydidae) from the Central Anatolia Region of Turkey. Journal of Freshwater Ecology, 21(3), 535-538 DOI: $10.1080 / 02705060.2006 .9665033$

Stamps, J. A., \& Swaisgood, R. R. (2007). Someplace like home: experience, habitat selection and conservation biology. Applied Animal Behaviour Science, 102(3), 392-409.

Stevenson, R. J., Bothwell, M. L., Lowe, R. L., \& Thorp, J. H. (1996). Algal ecology: Freshwater benthic ecosystem. Cambridge, USA: Academic Press.

Sweat, L. H., \& Johnson, K. B. (2013). The effects of fine-scale substratum roughness on diatom community structure in estuarine biofilms. Biofouling, 29(8), 879-890.

Tiffany, M. I. (2011). Epizoic and epiphytic diatoms. In J. Seckbach \& J. P. Kociolek (Eds.), Cellular origin, life in extreme habitats and astrobiology volume 19: the diatom world (pp. 195-209). London, England: Springer Publishing House.

Tumlison, R., \& Clark, S. (1996). Microorganisms associated with the carapace and plastron of aquatic turtles (Pseudemys concinna and Trachemys scripta) in southwestern Arkansas. Journal of the Arkansas Academy of Science, 50(1), 148-152.

Wetzel, C. E., Van de Vijver, B., Cox, E. J., Bicudo, D. D. C., \& Ector, L. (2012). Tursiocola podocnemicola sp. nov., a new epizoic freshwater diatom species from the Rio Negro in the Brazilian Amazon Basin. Diatom research, 27(1), 1-8.

Wetzel, C. E., Van de Vijver, B., \& Ector, L. (2010). Luticola deniseae sp. nov. a new epizoic diatom from the Rio Negro (Amazon hydrographic basin). Vie et Milieu Life and Environment, 60(3), 177.

Wu, S. C., \& Bergey, E. A. (2017). Diatoms on the carapace of common snapping turtles: Luticola spp. dominate despite spatial variation in assemblages. PloS one, 12(2), e0171910. 


\section{APPENDIX}

\section{Species and morph-species found in freshwater-turtles' carapaces}

\begin{tabular}{|c|c|c|}
\hline Order & Familiy & Species / morph-species \\
\hline Bacillariales & Bacillariaceae & $\begin{array}{l}\text { Hantzschia amphioxys } \\
\text { Nitzschia } \text { sp. }\end{array}$ \\
\hline Mastogloiales & Achnanthaceae & Achnanthes minutissima \\
\hline Cocconeidales & $\begin{array}{l}\text { Cocconeidaceae } \\
\text { Achnanthidiaceae }\end{array}$ & $\begin{array}{l}\text { Cocconeis placentula } \\
\text { Achnanthidium sp. }\end{array}$ \\
\hline Cymbellales & $\begin{array}{l}\text { Anomoeoneidacea } \\
\text { Cymbellaceae } \\
\text { Gomphonemataceae }\end{array}$ & $\begin{array}{l}\text { Anomoeoneis serians } \\
\text { Cymbella cistula } \\
\text { Encyonema silesiacum } \\
\text { Encyonema minutum } \\
\text { Gomphonema minutum } \\
\text { Gomphonema gracile } \\
\text { Gomphonema insigne } \\
\text { Gomphonema parvulum } \\
\text { Gomphonema } \text { sp. } 1 \\
\text { Gomphonema } \text { sp. } 2 \\
\text { Placoneis elginensis } \\
\text { Reimeria sinuata }\end{array}$ \\
\hline & Rhoicospheniaceae & Rhoicosphenia abbreviate \\
\hline Eunotiales & Eunotiaceae & $\begin{array}{l}\text { Actinella punctate } \\
\text { Eunotia bilunaris } \\
\text { Eunotia circumborealis } \\
\text { Eunotia soleirolii } \\
\text { Eunotia glacialis } \\
\text { Eunotia exigua } \\
\text { Eunotia bidentula }\end{array}$ \\
\hline Licmophorales & Ulnariaceae & Hannaea arcus \\
\hline Fragilariales & Fragilariaceae & Fragilaria sp. \\
\hline Aulacoseirales & Aulacoseiraceae & Aulacoseira sp. \\
\hline Naviculales & Diadesmidaceae & $\begin{array}{l}\text { Diadesmis contenta } \\
\text { Luticola mutica }\end{array}$ \\
\hline & Naviculaceae & $\begin{array}{l}\text { Navicula cryptotenella } \\
\text { Navicula trivialis } \\
\text { Navicula clementis } \\
\text { Navicula } \text { sp. } 1 \\
\text { Navicula } \text { sp. } 2\end{array}$ \\
\hline & Neidiaceae & Neidium dubium \\
\hline & Pinnulariaceae & $\begin{array}{l}\text { Pinnularia microstauron } \\
\text { Pinnularia borealis } \\
\text { Pinnularia viridis } \\
\text { Pinnularia stomatophora } \\
\text { Pinnularia balfouriana } \\
\text { Pinnularia lundii }\end{array}$ \\
\hline & Stauroneidaceae & Stauroneis anceps \\
\hline Rhopalodiales & Rhopalodiaceae & Epithemia sorex \\
\hline Tabellariales & Tabellariaceae & Tabellaria fenestrata \\
\hline
\end{tabular}

